\title{
Potato virus $Y$ (PVY) strains in Belgian seed potatoes and first molecular detection of the $\mathrm{N}$-Wi strain
}

\author{
Saman Bahrami Kamangar1,2, Guy Smagghe1, Martine Maes² \& Kris De Jonghe2,* \\ 1 Department of Crop Protection, Faculty of Bioscience Engineering, Ghent University, Coupure Links 653, 9000 Ghent, Belgium \\ 2 Institute for Agricultural and Fisheries Research (ILVO), Plant Sciences Unit, Burg. Van Gansberghelaan 96/2, 9820 Merelbeke, Belgium \\ * Corresponding author: kris.dejonghe@ilvo.vlaanderen.be
}

Received 10 April 2013, accepted 30 December 2013

\begin{abstract}
Potato virus $Y$ (PVY), one of the most important agents causing potato crop losses worldwide, is transmitted by a variety of aphid species in a non-persistent manner. Several PVY strains have been differentiated, all of them causing different symptoms and symptom expression levels on numerous commercial potato cultivars. In Belgium, strains belonging to the $\mathrm{N}$ group have been reported as the most prevalent, but no detailed information on the relative importance of the PVY strains in Belgium have been published to date.

We report here on a survey performed on Belgian seed potatoes harvested in 2010 in which 2700 individual tubers from 54 seed potato lots originating from 54 farms were screened for presence of PVY. The results revealed a high PVY incidence and substantial strain diversity in some farms. The dominance of the $\mathrm{N}$ group in Belgian seed potatoes was confirmed, while the $\mathrm{O}$ strain was only found in a few locations. Further characterization using multiplex PCR identified $75 \%$ of the isolates as NTN strains and $7.5 \%$ as Wilga strain (N-Wi). The presence of the N-Wi strain was confirmed and characterized for the first time in Belgian seed potato production.
\end{abstract}

Key words: PVYNTN, PVYN-Wi, Solanum tuberosum, strain variability, survey

\section{Introduction}

Potato virus $Y$ (PVY) is a major pathogen in potato production worldwide. The two main strain groups $\mathrm{O}$ and $\mathrm{N}$ are responsible for most of the damage in potato growing areas (Kerlan 2006, Rolot 2009). Apart from O and N, PVYC, PVYZ and $\mathrm{PVY}$ are also recognized as $\mathrm{PVY}$ strain groups (Karasev \& Gray 2013). Obvious mosaic, stunting and leaf drop are reported as the main symptoms of the $\mathrm{O}$ strain, whereas the $\mathrm{N}$ strain causes mild mosaic and occasional leaf necrosis (Singh et al. 2008). Over the past years, a lot of progress has been made in understanding the molecular properties of PVY strains. PVYO and PVYN are considered to be the two starting groups from which one to three recombinations resulted in several subgroups (Nie et al. 2013). Within the $\mathrm{N}$ strain group, the NTN strain (PVYNTN) is the causal agent of the potato tuber necrotic ringspot disease (PTNRD) (Beczner et al. 1984, Le Romancer et al. 1994). In some potato culti- vars, this strain can cause severe damage, both on leaves and tubers, whereas recombinants belonging to another $\mathrm{N}$-like subgroup containing the Wilga strain ( $\mathrm{PVY}^{\mathrm{N}-\mathrm{Wi}}$ ) (Chrzanowska 1991, Glais et al. 2001) and PVYN:O (Singh et al. 2003) mainly produce mild symptoms and can even remain latent in potato. However, symptoms caused by the same PVY strains can vary a lot depending on the potato cultivar (Nie et al. 2012). Molecular studies have revealed that even within the subgroups considerable variations in the PVY genome evolved differently, e.g. in North America and Europe, resulting in a very complex situation of strains, strain groups and variants (Karasev \& Gray 2013). However, these variations are mainly introduced by recombination in different parts of the genome (Glais et al. 2002, Nie \& Singh 2003a, Lorenzen et al. 2006a, Chikh Ali et al. 2007a, b, 2010b). Three to four recombinant junctions in NTN strains and only one or two recombinant junctions in $\mathrm{PVY}-\mathrm{N}-\mathrm{Wi}$ and PVYN:O have been reported (Glais et al. 2002, Nie \& Singh 2003a, Lorenzen et al. 2006a, b, Schubert et al. 2007, Visser et al. 2012, Karasev \& Gray 2013). Position and length of these recombinant segments, resulting in variations in recombinant junctions or breakpoints, have led to several publications on the existence of NTN variants ( $a$ and $b$ ) and on differentiating N-Wi \& N:O subgroups, which have been summarized in the recent reviews of Visser et al. (2012) and Karasev \& Gray (2013). Yet, fitness pressure selects and boosts the relative importance of some populations that have been created by point mutations and/or recombination. Geographic isolation could conduct different fitness pressure and natural selection to select and boost various recombinations, resulting in separate lineages, such as some $\mathrm{O}$ and Wilga strains in North America (the so called PVYO-O5 subgroup and PVYN:O) (Singh et al. 2008) and NA-PVYNTN that has evolved from NA-PVYN by mutation rather than recombination (Nie \& Singh 2003a).

Available data indicate that the $\mathrm{N}$ strain group (including PVYN, PVYNTN and PVYN-Wi strains) is the most common strain group in Europe (Weidemann 1988, Glais et al. 1998, Glais et al. 2002, Nie \& Singh 2003b), while in North America, the ordinary strain group (PVYO) still has a predominant place (Crosslin et al. 2006, Lorenzen et al. 2006a, Nanayakkara et al. 2012). Both in Germany (Lindner 2008) and Switzerland (Rigotti et al. 2011), the NTN-strain has been shown to be the most prevalent PVY strain, although both authors report a gradual shift over the years toward prevalence of the PVYN-Wi strain. This shift towards the 
Wilga strain was also reported in the Netherlands (Van der Vlugt et al. 2008, Verbeek 2009) and France (Kerlan et al. 1999). In France, the presence of Wilga, N, C, Z and O strains were reported, with $\mathrm{O}$ as the most dominant strain (Kerlan et al. 1999), but the spread of NTN in France was also reported recently (Blanchard et al. 2008).

The importance of the $\mathrm{N}$ strain for Belgium has also been demonstrated by Rolot \& Steyer (2008). In a more recent study, Rolot (2009) confirmed an increase in importance of the $\mathrm{N}$ strain group. Note that all of these records are based on serological tests that cannot differentiate between $\mathrm{N}$ and NTN. Additionally, $\mathrm{PVY} \mathrm{Y}^{\mathrm{N}} \mathrm{Wi}$ is serologically identified as an O strain (Singh et al. 2008).

PVY clearly has a large economic impact on potato seed production, but the various strains have a different impact depending on the symptoms they cause. Obtaining accurate data on the occurrence and prevalence of the different strains is thus important. The overall objective of this study is to support the seed potato certification scheme by means of a detailed characterization of the variability in PVY strains in Belgium and their relative importance.

\section{Materials and methods}

\section{PVY screening and collection of PVY isolates}

The survey was initiated with seed potatoes sampled on farms during the official certification scheme in 2010. Each sample consisted of 100 tubers. PVY incidence was screened using the grow-out method followed by the DAS-ELISA (Clark \& Adams 1977) test by polyclonal antibody (DSMZ, Germany) on the leaves. In each lot, the chosen plants were also assessed for symptom development. Individual PVYinfected plant samples were stored at $-70^{\circ} \mathrm{C}$ for further analysis.

\section{Strain determination}

Total plant RNA was extracted from maximum $100 \mathrm{mg}$ potato fresh leaf material using the Spectrum Plant Total RNA extraction Kit (Sigma, Bornem, Belgium). RNA yield and quality were checked spectrophotometrically (ND-1000 Spectrophotometer, NanoDrop, Isogen, Temse, Belgium).

First strand DNA was synthesized by adding $1 \mu \mathrm{l}$ of RNA template to $19 \mu \mathrm{l}$ of a mixture containing $1 \mu \mathrm{l}$ RevertAid Premium Reverse Transcriptase, $4 \mu \mathrm{l}$ 5x RT buffer, $1 \mu \mathrm{l}$ dNTP Mix (10 mM), $0.5 \mu$ Ribolock RNase inhibitor and Oligo-dT primer at a final concentration of $2.5 \mu \mathrm{M}$ (RT, Thermo Fisher Scientific, Waltham, MA, USA). The RT reaction was done at $42^{\circ} \mathrm{C}$ for 60 min followed by inactivation of the RT by heating at $95^{\circ} \mathrm{C}$ for $5 \mathrm{~min}$.

Multiplex PCR for strain differentiation was carried out according to Chikh Ali et al. (2010a) (primers listed in Table 1) with some modifications. PCR was conducted using OneTaq ${ }^{\mathrm{TM}}$ DNA Polymerase (Bioké, Leiden, the Netherlands) according to the following program: denaturation at $94^{\circ} \mathrm{C}$ for $4 \mathrm{~min}, 30$ cycles of denaturation at $94^{\circ} \mathrm{C}$ for $30 \mathrm{~s}$, annealing at $64^{\circ} \mathrm{C}, 62^{\circ} \mathrm{C}$ and $60^{\circ} \mathrm{C}$ in the first, second and third 10 cycles for $30 \mathrm{~s}$, respectively, and extension at $68^{\circ} \mathrm{C}$ for $5 \mathrm{~min}$. This was followed by a final $5 \mathrm{~min}$ extension step at $72^{\circ} \mathrm{C}$. PCR products were visualized using Qiaxel capillary electrophoresis (QIAxel Advanced System). The obtained amplicons were compared to the expected size (Chikh Ali et al. 2010a) and those of the PVY reference isolates that were included in the experiment.

The whole genome of the nine isolates was compiled (assembled using Codoncode and MEGA5 software) after amplifying nine segments and gaps using the primer pairs described by Nie \& Singh (2003a) and also designed in this study. Extra primer pairs were developed for additional sequencing of the overlapping regions of the nine segments (Table 1). PCR product purification and sequencing with the corresponding forward and reverse primers were performed by Macrogen Inc. (Amsterdam, the Netherlands). Consensus sequences of sense and antisense strands of all nine selected isolates were aligned and were deposited in GenBank and the accession numbers were linked to the isolate overview in Table 2. A phylogenetic dendrogram was compiled by means of UPGMA (Partial Deletion Gaps, Bootstrap test). The selected PVY isolates of this study were compared with a representative number of PVY isolates of the respective strain (sub)groups that were retrieved from the GenBank database (Table 3). A schematic diagram of the recombinant junctions (breakpoints) was drafted based on the RDP4 multiple recombination detection software (Martin et al. 2010).

\section{Results \\ Prevalence of PVY types in Belgium}

An overall general PVY infection rate of 3.6\%, ranging from $0 \%$ to a maximum of $42 \%$, was recorded in the 54 seed potato lots that were included in the survey. PVY infected tubers were identified in $42.5 \%$ (23/54) of the seed lots. A geographical distribution of samples positive for PVY, covering 23 administrative divisions in Belgium, is presented in Table 2.

\section{Strain Determination}

Forty PVY isolates were selected from PVY infected samples in ELISA tested from 21 locations in Belgium. They were subjected to strain determination using the multiplex RT-PCR protocol described by Chikh Ali et al. (2010a). As shown in Figures 1 and 2, analysis of the obtained fragments confirmed the presence of four strains and a variation ( $a$ and $b$ ) in NTN strains. These isolates were identified as NTN, O, $\mathrm{N}-\mathrm{Wi}$, and $\mathrm{N}$ with a relative abundance of $75 \%, 7.5 \%, 7.5 \%$, and $2.5 \%$, respectively. A minor percentage $(2.5 \%)$ of the infected plants revealed mixed infections with two or three strains (NTN and N-Wi and/or O), and $2.5 \%$ of the isolates could not be identified, probably also due to mixed infections (Fig. 1). 
Table 1: Primers used in this study

\begin{tabular}{|c|c|c|c|c|c|}
\hline Primer name & Polarity & Sequence (5'-3') & Location & Reference & Application \\
\hline n156 & + & GGGCAAACTCTCGTAAATTGCAG & $160-179$ & Chikh Ali et al. (2010a) & Multiplex RT-PCR - characterization \\
\hline 0514 & + & GATCCTCCATCAAAGTCTGAGC & $515-536$ & Chikh Ali et al. (2010a) & Multiplex RT-PCR - characterization \\
\hline n787 & - & GTCCACTCTCTTTCGTAAACCTC & $770-792$ & Chikh Ali et al. (2010a) & Multiplex RT-PCR - characterization \\
\hline n2258 & + & GTCGATCACGAAACGCAGACAT & $2260-2281$ & Lorenzen et al. (2006a) & Multiplex RT-PCR - characterization \\
\hline 02172 & + & CAACTATGATGGATTTGGCGACC & $2169-2191$ & Lorenzen et al. (2006a) & Multiplex RT-PCR - characterization \\
\hline n2650c & - & TGATCCACAACTTCACCGCTAACT & $2627-2650$ & Lorenzen et al. (2006a) & Multiplex RT-PCR - characterization \\
\hline 02700 & - & CGTAGGGCTAAAGCTGATAGTAG & $2678-2700$ & Chikh Ali et al. (2010a) & Multiplex RT-PCR - characterization \\
\hline S5585m & + & GGATCTCAAGTTGAAGGGGAC & $5578-5598$ & Lorenzen et al. (2006a) & Multiplex RT-PCR - characterization \\
\hline 06400 & - & GTAACTCCTAAACAAATGGTGGTTCG & $6405-6430$ & Chikh Ali et al. (2010a) & Multiplex RT-PCR - characterization \\
\hline n7577 & + & АСTGCTGCACCTTTAGATACTCTA & $7582-7605$ & Chikh Ali et al. (2010a) & Multiplex RT-PCR - characterization \\
\hline YO3-8648 & - & CTTTTCCTTTGTTCGGGTTTGAC & $8635-8657$ & Schubert et al. (2007) & Multiplex RT-PCR - characterization \\
\hline SeroN & - & GTTTCTCCTATGTCGTATGCAAGTT & $8864-8888$ & Chikh Ali et al. (2010a) & Multiplex RT-PCR - characterization \\
\hline \multirow[t]{2}{*}{1} & + & GGATCCAATTAAAACAACTCAATA & 5 ' end & Nie \& Singh 2003a & Sequencing \\
\hline & - & CATTTGTGCCCAATTGCC & $1091-1073$ & Nie \& Singh 2003a & Sequencing \\
\hline \multirow[t]{2}{*}{2} & + & TTCAGTTCTCAAGCGCTCAA & $1033-1052$ & Nie \& Singh 2003a & Sequencing \\
\hline & - & TCTTAGTGAAATCCTTTGCAT & $2133-2113$ & Nie \& Singh 2003a & Sequencing \\
\hline \multirow[t]{2}{*}{3} & + & GCGATGTTGATTAACATT & $2085-2102$ & Nie \& Singh 2003a & Sequencing \\
\hline & - & TTATTGCСTGACACACTGC & $3294-3276$ & Nie \& Singh 2003a & Sequencing \\
\hline \multirow[t]{2}{*}{4} & + & TCTTCAGGCGTTTGCCAACTTT & $3203-3224$ & Nie \& Singh 2003a & Sequencing \\
\hline & - & TTGCGCATCAACAAATGATTGG & $4367-4346$ & Nie \& Singh 2003a & Sequencing \\
\hline \multirow[t]{2}{*}{5} & + & TGTCAGCTACTCCAGTGGGAAG & $4266-4285$ & Nie \& Singh 2003a & Sequencing \\
\hline & - & TCAGTGCGCAATGTGTATGC & $5268-5250$ & Nie \& Singh 2003a & Sequencing \\
\hline \multirow[t]{2}{*}{6} & + & CACGAAATGCTTTGGGAAAC & $5169-5185$ & Nie \& Singh 2003a & Sequencing \\
\hline & - & CAGGAAACTTGGCAATGCCATT & 6198-6177 & Nie \& Singh 2003a & Sequencing \\
\hline \multirow[t]{2}{*}{7} & + & GCCACACAACCCACTCAAA & $6143-6161$ & Nie \& Singh 2003a & Sequencing \\
\hline & - & TCCGACTGCAGCTTTCAT & $7400-7383$ & Nie \& Singh 2003a & Sequencing \\
\hline \multirow[t]{2}{*}{8} & + & GGCTATCAATAGGGTTATCAT & 7289-7309 & Nie \& Singh 2003a & Sequencing \\
\hline & - & CTTGATGGTGCACTTCATAAG & $8571-8551$ & Nie \& Singh 2003a & Sequencing \\
\hline \multirow[t]{2}{*}{9} & + & GCTTTCACTGAAATGATGGT & $8502-8521$ & Nie \& Singh 2003a & Sequencing \\
\hline & - & GTTTTCCCAGTCACGACTTTTTTTTTTT & $3^{\prime}$ end & Nie \& Singh $2003 a$ & Sequencing \\
\hline $5 \mathrm{Pr}$ & - & ATCTGGACATCAGTCTTGTATC & & This study & Sequencing \\
\hline \multirow[t]{2}{*}{ Gap 1} & + & TGTCAACCAAAGGAGGGTCTG & & This study & Sequencing \\
\hline & - & ACCGGTTCAGTTAAGTGCTCT & & & \\
\hline \multirow[t]{2}{*}{ Gap 2} & + & AAATTGATCCAGCGAAGGGC & & This study & Sequencing \\
\hline & - & СТССТССТTСTСTGAАAGGTGA & & & \\
\hline \multirow[t]{2}{*}{ Gap3 } & + & ATGGTGTTGCAAGTTGTTAAGAA & & This study & Sequencing \\
\hline & - & CAGCATCGAACACCATGATGA & & & \\
\hline \multirow[t]{2}{*}{ Gap 4} & + & TTCAAGAAGCCAACACTGCG & & This study & Sequencing \\
\hline & - & GCAATGCTCCTATTGTCAATGTC & & & \\
\hline \multirow[t]{2}{*}{ Gap 5} & + & AACTTGCCAGTGATGACAGG & & This study & Sequencing \\
\hline & - & GCGCCTGCTATGATCAAGTC & & & \\
\hline \multirow[t]{2}{*}{ Gap 6} & + & GGTATGGGCAAGTCAAGCAG & & This study & Sequencing \\
\hline & - & ACAGGGAAATCTTTCGGCAT & & & \\
\hline \multirow[t]{2}{*}{ Gap 7} & + & ACAGGGAATTTGCAAGCTGT & & This study & Sequencing \\
\hline & - & TCTAAAGGTGCAGCAGTGAA & & & \\
\hline \multirow[t]{2}{*}{ Gap 8} & + & GACAGCACGTGTGTATTCTTTG & & This study & Sequencing \\
\hline & - & СTGTGATTGAGTTGCTCGAGT & & & \\
\hline $3 \mathrm{Pr}$ & + & GACAGCACGTGTGTATTCTTTG & & This study & Sequencing \\
\hline
\end{tabular}


Table 2: Sampling location, infection rate and PVY strain type for different potato cultivars to PVY in Belgian potato seed farms based on ELISA screening and RT-PCR strain typing. For nine selected isolates, the isolate ID and GenBank accession numbers are added

\begin{tabular}{|c|c|c|c|c|c|}
\hline Location & $\begin{array}{l}\text { No. of farms tested } \\
\quad(\text { total 54) }\end{array}$ & $\begin{array}{c}\% \text { Infected seed lots } \\
\text { (ELISA) }\end{array}$ & Cultivar & $\begin{array}{l}\text { Strain } \\
\text { (RT-PCR) }\end{array}$ & $\begin{array}{c}\text { Isolate ID and } \\
\text { GenBank } \\
\text { Accession No. }\end{array}$ \\
\hline \multirow[t]{2}{*}{ Adinkerke } & 1 & 16 & Eersteling & NTN & \\
\hline & & & & Mix (NTN \& O \& N-Wi) & \\
\hline \multirow[t]{2}{*}{ Amberloup } & 2 & 6 & Rode eersteling & Unknown & \\
\hline & & 4 & Spunta & NTN & \\
\hline \multirow[t]{3}{*}{ Assenede } & 3 & 0 & Draga & --- & \\
\hline & & 0 & Draga & --- & \\
\hline & & 0 & Draga & --- & \\
\hline \multirow[t]{3}{*}{ Boekhoute } & 3 & 0 & Marfona & --- & \\
\hline & & 0 & Marfona & --- & \\
\hline & & 8 & Paramount & NTN $\times 2$ & \\
\hline Brielen & 1 & 0 & Granola & --- & \\
\hline Ehein-Neupré & 1 & 2 & Spunta & NTN & \\
\hline Gistel & 1 & 0 & Spunta & --- & \\
\hline Grimbergen & 1 & 0 & --- & --- & \\
\hline \multirow[t]{3}{*}{ Hoeleden } & 3 & 0 & Diamant & --- & \\
\hline & & 0 & Diamant & --- & \\
\hline & & 0 & Diamant & --- & \\
\hline \multirow[t]{2}{*}{ Hompré } & 2 & 4 & Kennebec & NTN & \\
\hline & & 10 & Spunta & NTN $\times 2$ & JQ969033 \\
\hline Kieldrecht & 1 & 0 & Granola & --- & \\
\hline Koekelare & 1 & 0 & Desiree & --- & \\
\hline Langemark- & 2 & 4 & Spunta & NTN & \\
\hline Poelkapelle & & 0 & Marfona & --- & \\
\hline \multirow[t]{3}{*}{ Lo-Reninge } & 3 & 0 & Diamant & --- & \\
\hline & & 0 & Cara & --- & \\
\hline & & 2 & Cara & NTN & \\
\hline Méeffe & 1 & 0 & Diamant & --- & \\
\hline \multirow[t]{4}{*}{ Milmort } & 4 & 8 & Diamant & $\mathrm{N}$ & JQ969036 \\
\hline & & 2 & Diamant & NTN & JQ969037 \\
\hline & & 2 & Spunta & NTN & \\
\hline & & 4 & Spunta & NTN & \\
\hline \multirow[t]{6}{*}{ Moerbeke-Waas } & 6 & 0 & Spunta & --- & \\
\hline & & 0 & Spunta & --- & \\
\hline & & 0 & Draga & --- & \\
\hline & & 0 & Draga & --- & \\
\hline & & 0 & Draga & --- & \\
\hline & & 0 & Draga & --- & \\
\hline \multirow[t]{8}{*}{ Roeselare } & 8 & 0 & Marfona & --- & \\
\hline & & 0 & Marfona & --- & \\
\hline & & 0 & Spunta & --- & \\
\hline & & 10 & Spunta & NTN $\times 2$ & JQ969035 \\
\hline & & 14 & Spunta & NTN x2 & \\
\hline & & 18 & Anosta & NTN $x 2 \& N-W i \star$ & JQ969040* \\
\hline & & 10 & Anosta & $\mathrm{N}-\mathrm{Wi}$ & JQ969039 \\
\hline & & 2 & Spunta & NTN $\times 2$ & \\
\hline Sommière & 1 & 0 & Spunta & --- & \\
\hline
\end{tabular}


Table 2: (Continued)

\begin{tabular}{|c|c|c|c|c|c|}
\hline Location & $\begin{array}{l}\text { No. of farms tested } \\
\text { (total 54) }\end{array}$ & $\begin{array}{c}\% \text { Infected seed lots } \\
\text { (ELISA) }\end{array}$ & Cultivar & $\begin{array}{l}\text { Strain } \\
\text { (RT-PCR) }\end{array}$ & $\begin{array}{c}\text { Isolate ID and } \\
\text { GenBank } \\
\text { Accession No. }\end{array}$ \\
\hline \multirow[t]{2}{*}{ Tinlot } & 2 & 14 & Lady Rosetta & $0 \times 3$ & JQ969038 \\
\hline & & 0 & Hermes & --- & \\
\hline \multirow[t]{5}{*}{ Veurne } & 5 & 0 & Nicola & --- & \\
\hline & & 0 & Diamant & --- & \\
\hline & & 0 & Charlotte & --- & \\
\hline & & 4 & Nicola & $\mathrm{N}-\mathrm{Wi}$ & JQ969041 \\
\hline & & 2 & Charlotte & Unknown & \\
\hline Vlissegem & 1 & 6 & Spunta & NTN x2 & \\
\hline Wulpen & 1 & 42 & Bintje & NTN $x 7$ & JQ969034 \\
\hline
\end{tabular}

Table 3: Sequences retrieved from GenBank and used in phylogenetic analysis

\begin{tabular}{|c|c|c|}
\hline GenBank Accession No. & Strains & Country \\
\hline $\begin{array}{l}\text { JQ969033, JQ969035, JQ969037, JQ969034, JQ969039, JQ969040, } \\
\text { JQ969041, JQ969036, JQ969038 }\end{array}$ & NTN, N-Wi, N, O & Belgium \\
\hline JQ924285, JF928458, JF928459, JF928460 & O, E, NTN & Brazil \\
\hline AY166867, AY166866, U09509 & O, N, NTN & Canada \\
\hline 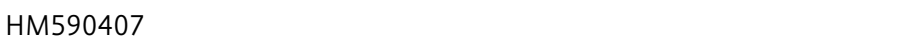 & O & China \\
\hline HM991454, AJ890348 & $\mathrm{C}, \mathrm{N}-\mathrm{Wi}$ & France \\
\hline HE608964, AJ889868, HE608963, AJ890346, AJ890347, AJ890350 & NTN, N-Wi & Germany \\
\hline JF927749, JF927761, JF927756, JF927752 & NTN & Hungary \\
\hline AB711154, AB711150, AB711149, AB714135 & $\mathrm{O}, \mathrm{N}$ & Japan \\
\hline AM268435 & $\mathrm{N}$ & New Zealand \\
\hline EU563512 & $\mathrm{C}$ & the Netherlands \\
\hline JF795485, AJ890343, AJ890342, AJ889866 & NTN, N-Wi, N & Poland \\
\hline X97895 & $\mathrm{N}$ & Switzerland \\
\hline AB270705 & $\mathrm{N}$ & Syria \\
\hline AJ585195, AJ585198, AJ585197, JX424837 & $\mathrm{O}, \mathrm{N}$ & United Kingdom \\
\hline \multicolumn{3}{|l|}{ HQ912892, HQ912891, HQ912897, HQ912914, HQ912913, HQ912884, } \\
\hline HQ912874, HQ912868, HQ912896, HQ912863, HQ912871, HQ912862, & O, O5, N-Wi, N:O, NTN, & United States of America \\
\hline HQ912872, HQ912870, HQ912869, HQ912890, HQ912893, HQ912864, & NA_PVY-N & \\
\hline \multicolumn{3}{|l|}{ FJ643478, EF026074, EF026076, FJ204166, FJ204165, FJ204164, } \\
\hline \multicolumn{3}{|l|}{ EF026075, EF026074, AY884983, AY884984 } \\
\hline NC_004039 & Potato virus $A$ & Hungary \\
\hline NC_004010 & Potato virus V & United Kingdom \\
\hline M96425, NC_001517 & Pepper Mottle virus & United States of America \\
\hline
\end{tabular}

The obtained virtual banding patterns of the PCR products of a selection of representative PVY isolates and reference isolates (JKI, Germany) produced with the six primer pairs of the multiplex RT-PCR is presented in Fig. 2. Phylogenetic analysis of the sequences (Fig. 3) was in a good correspondence with the multiplex banding pattern, except for GBVC_PVY_15 NTN (JQ969034).

Based on the banding patterns in the multiplex PCR, three isolates in this study were identified as Wilga strains
(GBVC_PVY_26 N-Wi (JQ969039), GBVC_PVY_23 N-Wi (JQ969040) and GBVC_PVY_34 N-Wi (JQ969041)). The phylogenetic analysis confirmed the attribution to the Wilga subgroup and revealed that all three isolates cluster in the N-Wi subgroup, (Nie \& Singh 2003b, Karasev et al. 2011, Karasev \& Gray 2013, Visser et al. 2012). However, the variability between the Wilga strain (GBVC_PVY_23 N-Wi (JQ969040) and GBVC_PVY_26 N-Wi (JQ969039)) from two infected Anosta lots from the same location (Roeselare) 


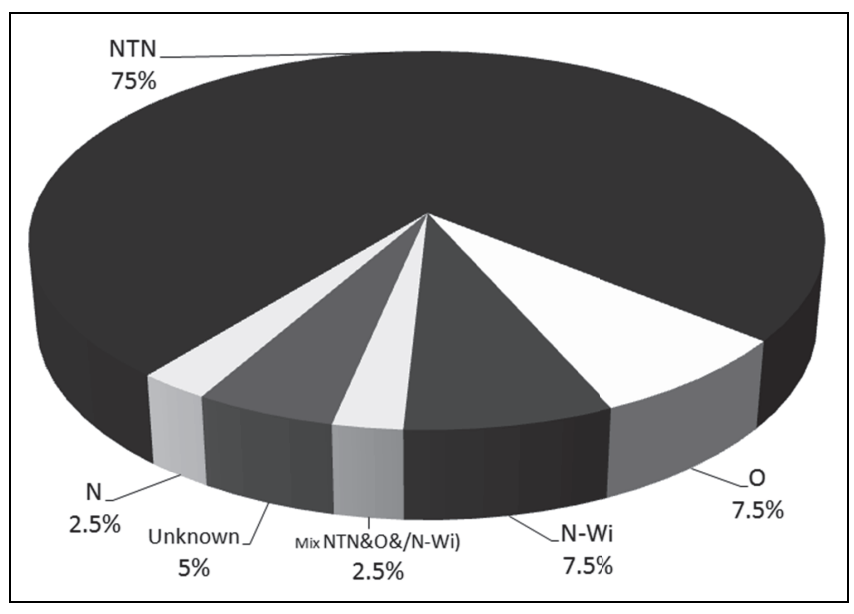

Fig. 1: Prevalence of the different PVY strains on naturally infected seed potato cultivars in Belgium as determined by multiplex RT-PCR.

was also significant with both isolates clustering in different clades (Fig. 3). Additionally, the recombination pattern of all three Wilga strains was similar showing two breakpoints at RJ1 and RJ2 which is corresponding to the other $\mathrm{N}-\mathrm{Wi}$ strains of which the complete sequence is available in GenBank (Fig. 4).

Four isolates that were identified as NTN strains by means of the multiplex PCR were also fully characterized. The multiplex PCR banding pattern (Fig. 2) produced two bands (441 and 1307 bp) for GBVC_PVY_15 NTN (JQ969034) and three for other NTN isolates. Based on this difference, Chikh Ali et al. (2010a) differentiated the isolates into type A (GBVC_PVY_3 NTN (JQ969035), GBVC_PVY_9 NTN (JQ969037) and GBVC_PVY_37 N_NTN (JQ969033)) and type B (GBVC_PVY_15 NTN (JQ969034)). However, based on the full genome sequence analysis (Fig. 3), the Belgian isolates were all identified as NTNa (type A) as described in the review of Karasev \& Gray (2013), clustering in a major clade with other NTNa strains. The NTNb reference isolates which were retrieved from GenBank cluster in a separate small clade, also contained the NTN strain AJ889866 (Schubert et al. 2007) from Poland. Additionally, this was also confirmed by the recombination map (Fig. 4) of the NTN isolates in this study that showed three breakpoints, corresponding to RJ2, RJ3 and RJ4, and identified all of them as NTN type A after Karasev \& Gray (2013).

The alleged O strain (GBVC_PVY_20 O (JQ969038)) also clustered in the same group together with $\mathrm{O}$ strains from US, EU and Japan that were deposited in GenBank (Fig. 3). Additionally, the suspected N (GBVC_PVY_10 N (JQ969036)) clustered with the corresponding $\mathrm{N}$ strains that are available in GenBank, including N Mont (AY884983), N 605 (X97895) and $\mathrm{N}$ New Zealand (Fig. 3). PVYE, PVYC strains and other potyviruses (Potato virus $A$ and $\mathrm{V}$ and Pepper Mottle virus) were also included in the phylogenetic analysis and clustered significantly different from all isolates (Fig. 3).

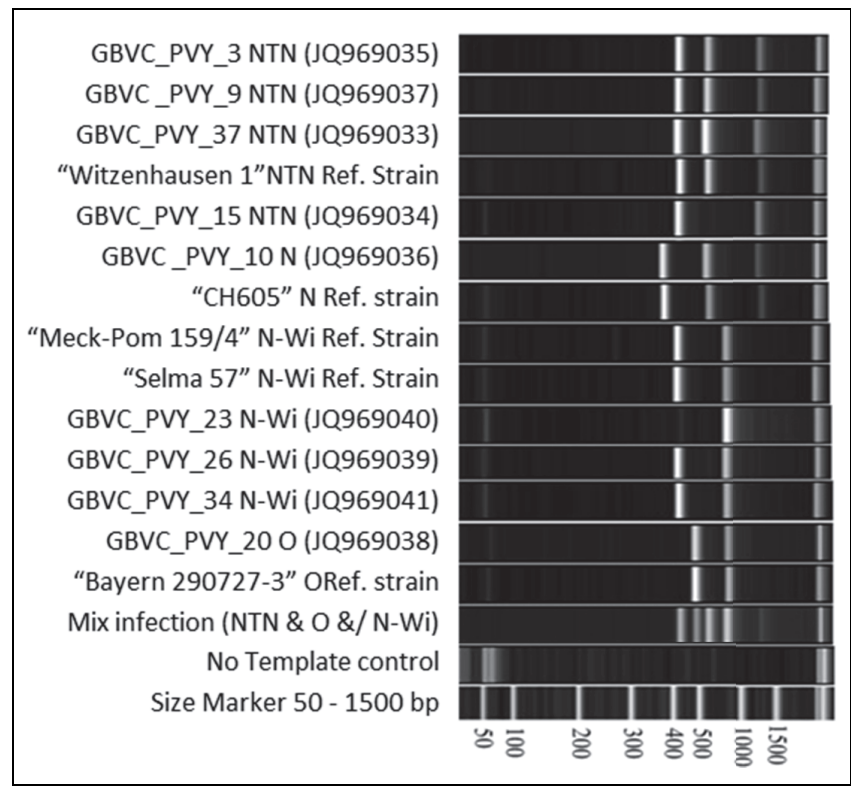

Fig. 2: Virtual banding patterns of PCR products of representative PVY isolates and standards, produced with the six primer pairs of Chikh Ali et al. (2010a). NTC: no template control. The JKI (Julius Kuhn Institute, Braunschweig, Germany) reference ID for the reference isolates is indicated between quotation marks: N-Wi2 = "Selma 57"; N-Wi3 = "Meck-Pom 159/4"; O = "Bayern 290727-3"; N = "CH605"; NTN = "Witzenhausen 1".

Symptoms, strain and potato cultivar relation

The seed potato samples infected with the Wilga strain belonged to the cultivars Anosta and Nicola were collected in Veurne and Roeselare (Table 2). The most prevalent strain (NTN) was detected in the following cultivars: Spunta, Diamant, Bintje, Eersteling, Anosta, Paramount, Cara and Kennebec.

PVY-infected plants ranged from symptomless to mottling, mild and severe mosaic and leaf malformation. Tissue necrosis and stunting were only occasionally observed. Cultivar 'Spunta', produced on 21 farms, was found to be mainly infected with NTN and showed symptoms ranging from mild mosaic to leaf necrosis. $\mathrm{N}$ mainly caused mosaic, while $\mathrm{O}$ and N-Wi symptom development was more variable, ranging from symptomless to mottling, mild to severe mosaic and growth reduction on several cultivars. No clear correlation between the symptoms and the cultivars could be recorded.

\section{Discussion}

Based on the ELISA screening results, the average of PVY infection rate of $3.6 \%$ in Belgian seed potato farms in our study was slightly higher than the rate $(2.4 \%)$ obtained in 2007 (Rolot 2009). In agreement with the report of Rolot (2009), our results also confirmed that the N strain group (NTN, N-Wi and N strains) is the most prevalent (89.5\%) in Belgium. In accordance with published data from other 


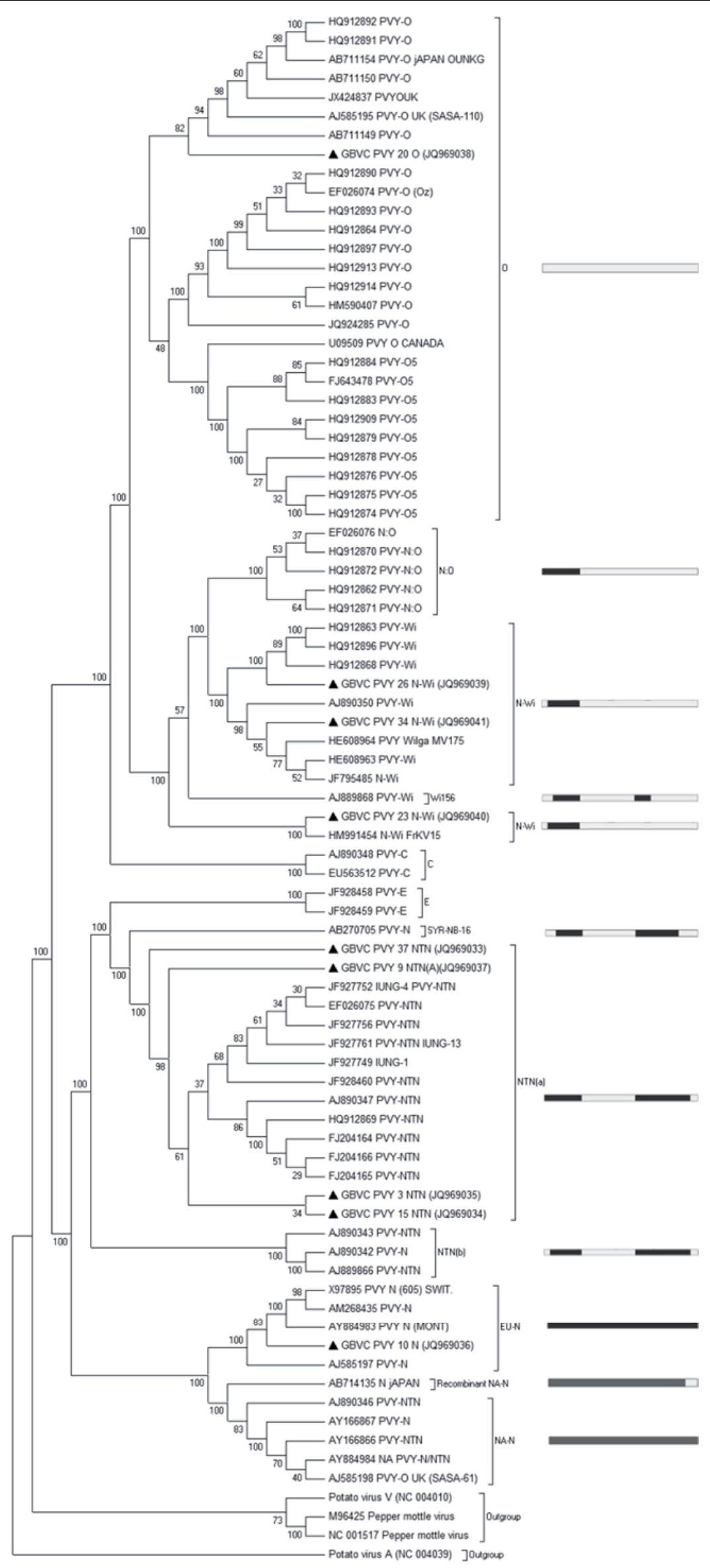

Fig. 3: Phylogenetic analysis of PVY isolates from Belgian seed potato production (this study) $(\boldsymbol{\Delta})$. All reference sequences are retrieved from GenBank (http://www.ncbi. nlm.nih.gov). Statistical Methods: Neighbour-joining test, test of phylogeny (bootstrap values are indicated on the nodes), evolutionary analyses were conducted with MEGA5. The bars represent schematic recombination maps of the respective strain groups. 

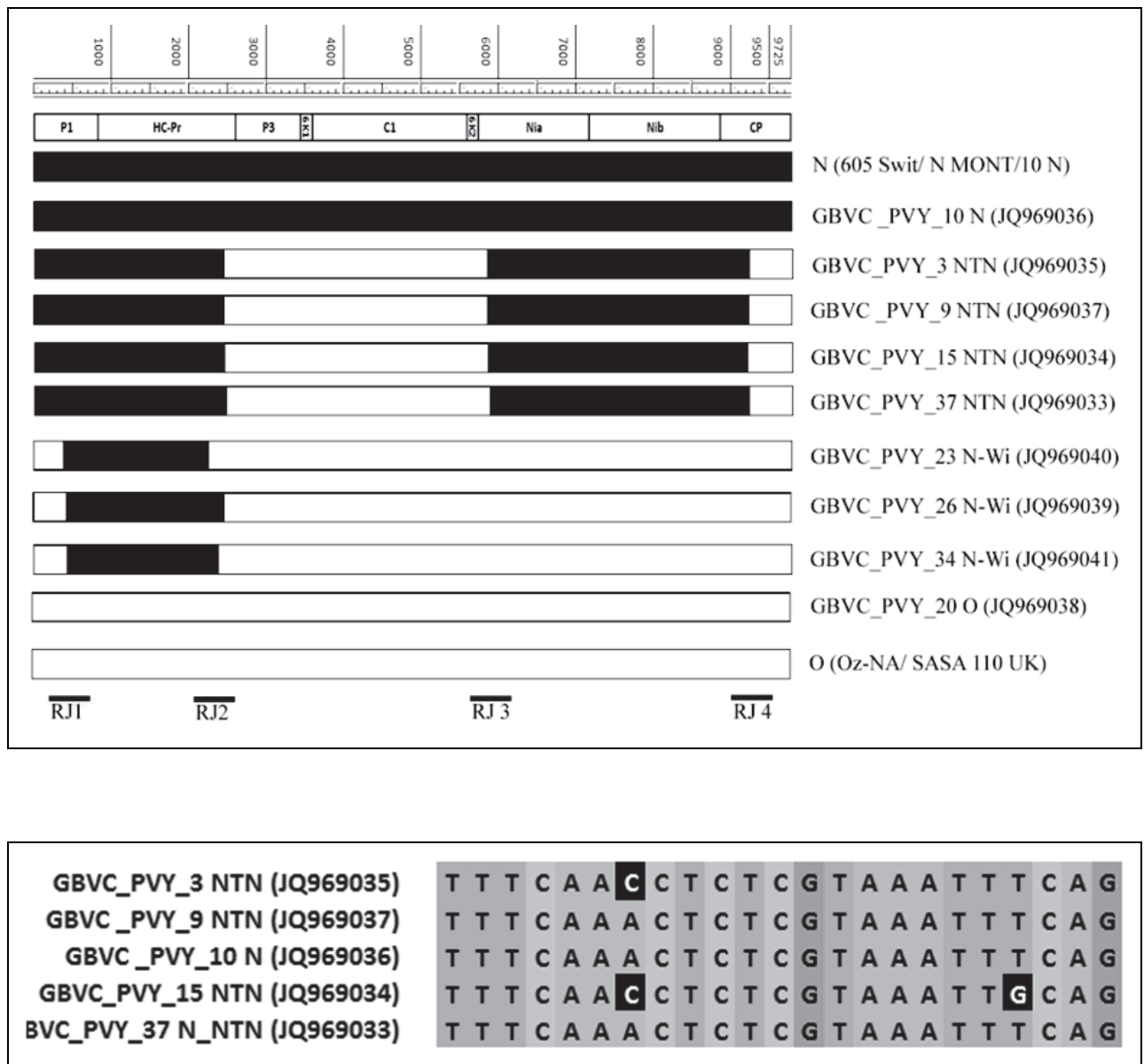

Fig. 4: Schematic recombination map of nine selected PVY isolates compiled by the RDP 4 multiple recombination detection software. RJ: recombination junction.
Fig. 5: Comparison of sequence of annealing sites of the NTN strains with relevant forward primer (n156) (Chikh Ali et al. 2010a). Base variations are indicated in black squares. important West European potato growing areas, this study confirmed the relative importance of the NTN strain compared to the specific N strain. However, the percentage NTN strains that was detected $(75 \%)$ was lower than what was recorded in Germany (Lindner 2008), the Netherlands (Verbeek 2009) and Switzerland (Rigotti et al. 2011).

The NTN population collected in Belgium did not consist of homogenous isolates based on analysis using the PCR method of Chikh Ali et al. (2010a). Presence or absence of the $633 \mathrm{bp}$ amplicon is discriminative between NTN variants (A and B) and indicates the presence or absence of an extra recombinant junction (RJ1) at the 5 'end. NTNb therefore starts with a small segment of the O strain (Chikh Ali et al. 2010a, Karasev \& Gray 2013). GBVC_PVY_15 NTN (JQ969034) lacked this $633 \mathrm{bp}$ amplicon, but sequence analysis revealed that this was rather due to a base replacement at a critical position (Fig. 5) at the annealing site with the relevant forward primer (n156) (Chikh Ali et al. 2010a), rather than a recombination on which the actual $\mathrm{A}$ and $\mathrm{B}$ typing is based (Karasev \& Gray 2013). We recommend that future sequence analysis on sufficiently large fragments of the genome in the $\mathrm{RJ}$ regions allowing to reconstitute recombination maps, or ideally, full genome sequencing is necessary to accurately type PVY isolates.

Our results confirmed the presence of N-Wi strain in Belgian seed potatoes for the first time. In addition, the phylogenetic tree also showed that the Belgian Wilga isolates clustered in the different interior branch of the European and American Wilga isolates (Fig. 3) (Glais et al. 2002, Nie \& Singh 2003b). Additional pathological and biological characterization of these isolates is necessary to further type the NTN and N-Wi populations. This would also allow researchers to further categorize the NTN strain into PVYNTN Hun (European PVYNTN) and PVYNTN-Tu 660 (North American PVYNTN), the two NTN types identified and discussed by several research groups (Thole et al. 1993, Nie \& Singh 2002, 2003a, b, Piche et al. 2004, Chikh Ali et al. 2007b, 2010b, Hu et al. 2009, 2011).

In summary, this study presented the relative distribution of the PVY strains across seed potato lots in Belgium. We could conclude that NTN is the most dominant strain in all parts of Belgium and that the NTN isolates belong to the NTNa type. Additionally, the presence of the Wilga strain was confirmed and genetically fully characterized for the first time in Belgium. All Wilga strains belong to the $\mathrm{N}-\mathrm{Wi}$ subgroup and no N:O variants were identified. The other strains, O, and PVY-N, appeared less important and were also more restricted in their geographical distribution. No PVYC, PVYE or PVYZ was put in evidence.

\section{Acknowledgements}

The authors thank Dr. K. Lindner (JKI, Braunschweig, Germany) for kindly providing the PVY reference isolates used in this study. 


\section{References}

Beczner L, Horvath H, Romhanyi L \& Foster H, 1984. Ethiology of tuber necrotic ringspot disease in potato. Potato Res 27, 339-352.

Blanchard A, Rolland M, Delaunay A \& Jacquot E, 2008. An International Organization to improve knowledge on Potato Virus $Y$. INRA online publication.

Chikh Ali M, Maoka T \& Natsuaki KT, 2007a. A point mutation changes the serotype of a potato virus Y isolate; genomic determination of the serotype of PVY strains. Virus Genes 35, 359-367.

Chikh Ali M, Maoka T \& Natsuaki KT, 2007b. The occurrence and characterization of new recombinant isolates of PVY displaying shared properties of PVYNW and PVYNTN. J Phytopathol 155, 409-415.

Chikh Ali M, Maoka T, Natsuaki KT \& Natsuaki T, 2010a. The simultaneous differentiation of Potato virus $Y$ strains including the newly described strain PVYNTN-NW by multiplex PCR assay. J Virol Methods 165, 15-20.

Chikh Ali M, Maoka T, Natsuaki T \& Natsuaki KT, $2010 \mathrm{~b}$. PVYNTN-NW, a novel recombinant strain of Potato virus Y predominating fields in Syria. Plant Pathol 59, 31-41.

Chrzanowska M, 1991. New isolates of the necrotic strain of potato virus $\mathrm{Y}\left(\mathrm{PVY}^{\mathrm{N}}\right)$ found recently in Poland. Potato Res 34, 179-182.

Clark MF \& Adams AN, 1977. Characteristics of the microplate method of enzyme-linked immunosorbent assay for the detection of plant viruses. J Gen Virol 34, 475483.

Crosslin JM, Hamm PB, Hane DC, Jaeger J, Brown CR, Shiel PJ, Berger PH \& Thornton RE, 2006. The occurrence of $\mathrm{PVYO}, \mathrm{PVY}^{\mathrm{N}}$, and $\mathrm{PVYN}: \mathrm{O}$ strains of Potato virus $Y$ in certified potato seed lot trials in Washington and Oregon. Plant Dis 90, 1102-1105.

Glais L, Tribodet M, Gauthier JP, Astier-Manifacier S, Robaglia C \& Kerlan C, 1998. RFLP mapping of ten viral isolates representative of different biological groups of potato virus Y. Arch Virol 143, 1-15.

Glais L, Tribodet M \& Kerlan C, 2001. Molecular detection of particular PVY isolates: PVYNTN and PVYNW. Proceedings of the 11th EAPR Virology Section Meeting, Havlickuv Brod - Trest, Czech Rep, 70-71.

Glais L, Tribodet M \& Kerlan C, 2002. Genomic variability in Potato potyvirus Y (PVY): evidence that PVYNW and PVYNTN variants are single to multiple recombinants between $\mathrm{PVYO}$ and PVYN isolates. Arch Virol 147, 363-378.

$\mathrm{Hu}$ X, Karasev AV, Brown CJ \& Lorenzen JH, 2009. Sequence characteristics of potato virus Y recombinants. J Gen Virol 90, 3033-3041.

Hu X, Nie X, He C \& Xiong X, 2011. Differential pathogenicity of two different recombinant PVYNTN isolates in Physalis floridana is likely determined by the coat protein gene. Vir J 8, 207 (5p).

Karasev AV \& Gray SM, 2013. Continuous and emerging challenges of Potato virus $Y$ in potato. Annu Rev Phytopathol 51, 571-581.

Karasev AV, Hu X, Brown CJ, Kerlan C, Nikolaeva OV, Crosslin JM \& Gray SM, 2011. Genetic diversity of the ordinary strain of Potato virus $Y$ (PVY) and origin of recombinant PVY strains. Phytopathology 101, 778-785.

Kerlan C, 2006. Potato Virus Y. Descriptions of plant viruses, No. 414, the Association of Applied Biologists (AAB), UK.

Kerlan C, Tribodet M, Glais L \& Guillet M, 1999. Variability of Potato virus $Y$ in potato crops in France. J Phytopathol 147, 643-651.

Le Romancer M, Kerlan C \& Nedellec M, 1994. Biological characterization of various geographical isolates of Potato virus $Y$ inducing superficial necrosis on potato tubers. Plant Pathol 43, 138-144.

Lindner K, 2008. PVY strains in Germany - the period between 1984 and 2006. Report of the 13th European Association for Potato Research Virology Section Meeting, Coylumbridge, Scotland. Potato Res 51, 202.

Lorenzen JH, Meacham T, Berger PH, Shiel PJ, Crosslin JM, Hamm PB \& Kopp H, 2006a. Whole genome characterization of Potato virus $Y$ isolates collected in the western USA and their comparison to isolates from Europe and Canada. Arch Virol 151, 1055-1074.

Lorenzen JH, Piche LM, Gudmestad NC, Meacham T \& Shiel P, 2006b. A multiplex PCR assay to characterize Potato virus $Y$ isolates and identify strain mixtures. Plant Dis 90, 935-940.

Martin DP, Lemey P, Lott M, Moulton V, Posada D \& Lefeuvre P, 2010. RDP3: a flexible and fast computer program for analyzing recombination. Bioinformatics 26, 2462-2463.

Nanayakkara UN, Singh M, Pelletier Y \& Nie X, 2012. Investigation of Potato virus $Y$ (PVY) strain status and variant population in potatoes in New Brunswick, Canada. Am J Pot Res 89, 232-239.

Nie B, Singh M, Murphy A, Sullivan A, Xie C \& Nie X, 2012. Response of potato cultivars to five isolates belonging to four strains of Potato virus Y. Plant Dis 96, 1422-1429.

Nie X \& Singh RP, 2002. Probable geographical grouping of PVYN and PVYNTN based on sequence variation in P1 and 5'-UTR of PVY genome and methods for differentiating North American PVYNTN. J Virol Methods 103, 145-156.

NieX \& Singh RP, 2003a. Evolution of North American PVYNTN strain Tu 660 from local PVYN by mutation rather than recombination. Virus Genes 26, 39-47.

Nie X \& Singh RP, 2003b. Specific differentiation of recombinant PVY(N:O) and PVY(NTN) isolates by multiplex RT-PCR. J Virol Methods 113, 69-77.

Nie X, Singh M, Pelletier Y \& McLaren D, 2013. Recent advances on Potato virus $Y$ Research in Canada. Am J Potato Res 90, 14-20.

Piche LM, Singh RP, Nie X \& Gudmestad NC, 2004. Diversity among potato virus y isolates obtained from potatoes grown in the United States. Phytopathology 94, 1368-1375.

Rigotti S, Balmelli C \& Gugerli P, 2011. Census report of the Potato virus $Y$ (PVY) population in Swiss seed potato production in 2003 and 2008. Potato Res 54, 105-117.

Rolot JL, 2009. Proportion of necrotic and ordinary PVY strains in the Belgian potato seeds production (2007) on an ELISA test basis. PVY Meeting Wide Organization Paris, June 2009, 8th- $9^{\text {th }}$.

Rolot JL \& Steyer S, 2008. First screenings of the different PVY strains in Belgium. Report of the $13^{\text {th }}$ European Association 
for Potato Research Virology Section Meeting, Coylumbridge, Scotland. Potato Res 51, 204-205.

Schubert J, Fomitcheva V \& Sztangret-Wisniewska J, 2007. Differentiation of Potato virus $Y$ strains using improved sets of diagnostic PCR-primers. J Virol Methods 140, 66-74.

Singh RP, Valkonen JPT, Gray S, Boonham N, Jones RA, Kerlan C \& Schubert J, 2008. Discussion paper: The naming of Potato virus $Y$ strains infecting potato. Arch Virol 153, 1-13.

Singh RP, McLaren DL, Nie X \& Singh M, 2003. Possible escape of a recombinant isolate of Potato virus $Y$ by serological indexing and methods of its detection. Plant Dis 87, 679-685.

Thole V, Dalmay T, Burgyan J \& Balazs E, 1993. Cloning and sequencing of potato virus $Y$ (Hungarean isolate) genomic RNA. Gene 123, 149-156.
Van der Vlugt RAA, Verbeek M, Cuperus C, Piron PGM, de Haan E \& van de Bovenkamp GW, 2008. Strains of Potato virus $Y$ in Dutch seed potato culture. Report of the $13^{\text {th }}$ European Association for Potato Research Virology Section Meeting, Coylumbridge, Scotland. Potato Res 51, 191-192.

Verbeek M, 2009. Aphid transmission of Potato virus Y. Bioforsk FOKUS 4, 180-181.

Visser JC, Bellstedt DU \& Pirie MD, 2012. The recent recombinant evolution of a major crop pathogen, Potato virus $Y$. PloS ONE 7(11): e50631.doi:10.1371/journal.pone. 0050631.

Weidemann $\mathrm{H}$, 1988. Importance and control of potato virus $Y N$ (PVYN) in seed potato production. Potato Res 31, 85-94. 